\title{
Investigating the entrepreneurial intentions of social grant recipients in the cities of Johannesburg and Tshwane
}

\begin{tabular}{|c|c|}
\hline \multicolumn{2}{|c|}{$\begin{array}{l}\text { Authors: } \\
\text { Boitumelo Masilela }{ }^{1} \text { (D) } \\
\text { John Pangala }{ }^{1} \text { (D) } \\
\text { Jurie van Vuuren }{ }^{1} \text { (D) }\end{array}$} \\
\hline \multicolumn{2}{|c|}{$\begin{array}{l}\text { Affiliations: } \\
\text { }{ }^{1} \text { Department of Business } \\
\text { Management, Faculty of } \\
\text { Economic and Management } \\
\text { Sciences, University of } \\
\text { Pretoria, Pretoria, } \\
\text { South Africa }\end{array}$} \\
\hline \multicolumn{2}{|c|}{$\begin{array}{l}\text { Corresponding author: } \\
\text { John Pangala, } \\
\text { pangalajohn@gmail.com }\end{array}$} \\
\hline \multicolumn{2}{|c|}{$\begin{array}{l}\text { Dates: } \\
\text { Received: } 01 \text { Aug. } 2019 \\
\text { Accepted: } 05 \text { June } 2020 \\
\text { Published: } 31 \text { Aug. } 2020\end{array}$} \\
\hline \multicolumn{2}{|c|}{$\begin{array}{l}\text { How to cite this article: } \\
\text { Masilela, B., Pangala, J., \& } \\
\text { Van Vuuren, J. (2020). } \\
\text { Investigating the } \\
\text { entrepreneurial intentions of } \\
\text { social grant recipients in the } \\
\text { cities of Johannesburg and } \\
\text { Tshwane. South African } \\
\text { Journal of Business } \\
\text { Management 51(1), a1716. } \\
\text { https://doi.org/10.4102/ } \\
\text { sajbm.v51i1.1716 }\end{array}$} \\
\hline \multicolumn{2}{|c|}{$\begin{array}{l}\text { Copyright: } \\
\text { (C) 2020. The Authors. } \\
\text { Licensee: AOSIS. This w } \\
\text { is licensed under the } \\
\text { Creative Commons } \\
\text { Attribution License. }\end{array}$} \\
\hline \multicolumn{2}{|l|}{ Read online: } \\
\hline 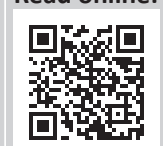 & $\begin{array}{l}\text { Scan this QR } \\
\text { code with your } \\
\text { smart phone or } \\
\text { mobile device } \\
\text { to read online. }\end{array}$ \\
\hline
\end{tabular}

Purpose: The primary aim of this study was to investigate the entrepreneurial intentions of social grant recipients in the cities of Johannesburg and Tshwane. This study further investigated the extent to which social grants influence the entrepreneurial behaviour of social grant recipients.

Design/methodology/approach: A descriptive cross-sectional survey design was adopted. Primary data were collected using a structured questionnaire randomly targeting social grant recipients at various SAPO branches and SASSA pay-points. To test the hypotheses, the data collected from 401 respondents in the cities of Johannesburg and Tshwane was analysed on the SPSS statistics software (version 25).

Findings/results: It was discovered that most of the respondents intended to start a business in the absence of a social grant income. Although SASSA grant holders indicated that they intended to start businesses, $70 \%$ of the respondents had no knowledge of any public or private business support initiatives and had not been to any entrepreneurial training sessions offered by the public or private sector. The respondents within the youth age group who indicated interest to start a business also expressed their desire for immediate gratification. Given that an entrepreneurial career requires a long-term vision, persistence and perseverance, this is indicative of a lack of entrepreneurial intensity.

Practical implications: In order to increase social grant recipients' entrepreneurial intentions and possibly reduce the number of youth social grant recipients currently in the system, government stakeholders should include the existing public and private entrepreneurship support initiatives within South African Social Security Agency (SASSA) policies.

Originality/value: With the application of quantitative methodologies, this research contributes to an evidence-based debate on the extent to which social grants influence the entrepreneurial behaviour of social grant recipients within the Republic of South Africa.

Keywords: City of Johannesburg; City of Tshwane; entrepreneurship; entrepreneurial intentions; motivation; proactivity; risk taking; social grant recipients; social grants; quantitative study.

\section{Introduction}

Despite South Africa being considered one of the economic powerhouses of the African continent, studies have indicated that South Africa's entrepreneurial growth rate is still very low when compared to other African countries. In the face of a low entrepreneurship growth rate, there has been an increase of social grant recipients from 2.5 million beneficiaries in 1998 to over 17.6 million in 2018 (Department of Social Development, 2018; Mabugu, Chitiga, Fofana, Abidoye, \& Mbanda, 2014). This means $31 \%$ of the population is on social grants.

There are growing concerns regarding the sustainability of social assistance in the long run. The former Presidents, Mr Thabo Mbeki and, more latterly, Mr Jacob Zuma, were quoted during their presidential tenures, saying the state could not rely on, nor sustain a permanent social grants system (City Press, 2011; Mbeki, 2007). The former finance minister, Mr Trevor Manuel, also warned against social assistance creating a tendency (or culture) of dependency (Surender, Noble, Wright, \& Ntshongwana, 2010). Zondo (2017), a former social grant recipient, stated in an article that grant recipients should not rely on social assistance as a sustainable means of living, but should use the grants as leverage out of poverty. The economic participation of the youth through entrepreneurship is a solution that has been supported by the South African National Civic Organisation (SANCO) (The Citizen, 2017).

Entrepreneurship has been found to be an intentional and planned behaviour (Shane \& Venkataraman, 2000, p. 218). Entrepreneurial activities increase economic efficiency through 
innovation and growth, creating new jobs and, consequently, reducing unemployment levels (Small Enterprise Development Agency, 2016). By providing the right entrepreneurial education and promoting successful entrepreneurs, an environment is created that significantly influences the motivation of the youth to engage in entrepreneurial activities (Chinyamurindi, 2016; Chowdhury, Desai, \& Audretsch, 2018; Khuong \& An, 2016).

The South African policy-makers have devised various initiatives, dating back to 1994, to improve the economy and reduce levels of poverty and unemployment (Brière, Tremblay, \& Daou, 2014, p. 17). One such policy, intended to provide social assistance to the disadvantaged in South Africa, is known as the Social Grant System (Department of Social Development, 2015). A recent survey undertaken amongst agricultural entrepreneurs in a rural part of KwaZulu-Natal has indicated that there is a dependency on social grants which is affecting the growth entrepreneurship in the area (Sinyolo, Mudhara, \& Wale, 2017, p. 66).

Nevertheless, there is no specific study that has been conducted to establish whether a relationship exists between the rising population of social grant recipients and declining entrepreneurial intentions (EIs). The goal of this quantitative study was to investigate the extent to which the EIs of social grant recipients in the City of Johannesburg and the City of Tshwane are influenced by income from social grants. This study, first, provides an overview of the South African social assistance programme. Second, the study reviews the existing literature on social grant dependency, EIs and entrepreneurial behaviour. Finally, the hypotheses being tested are presented, followed by the findings, recommendations and conclusion of the study.

\section{Literature review}

\section{Social grants landscape in South Africa Brief history of the social welfare system}

Social assistance, predominantly intended to provide for poor white citizens, can be traced back to the 1920s in South Africa (Groenmeyer, 2016). The European concept of income transfers for vulnerable and needy individuals was the basis on which social assistance in South Africa was modelled (Mitileni \& Sithole, 2016, p. 246). However, this assistance was racially and politically inclined. Initially, as said, it was restricted to poor white people and only later incorporating the other racial groups of Indians, mixed race and black people (Groenmeyer, 2016, pp. 139-140; Mitileni \& Sithole, 2016). Following this, the social grant system that was later introduced in South Africa to reform the social welfare system was biased, excluding black individuals as beneficiaries (Bengtsson, 2010). When the new governing party came into power in 1994, the Constitution of South Africa reaffirmed that social assistance would be prioritised (Mitileni \& Sithole, 2016). In 1995, the Lund Committee was established to assess several policies as well as to make recommendations on the re-design of social assistance (Hall, 2010). As a result, Section 27 (1)(c) of the Constitution of South Africa was finalised and, to date, states [that] 'everyone has the right to have access to ... social security, ... if they are unable to support themselves and their dependants...' (South Africa, 1996:S27 (1)(c)).

A range of social services were subsequently implemented under the auspices of the South African Social Security Agency (SASSA) to provide social assistance to the underprivileged and manage the social problems in South Africa (Department of Social Development, 2013, 2015).

\section{Means test}

The SASSA uses the means test as one of the determinants to assess whether an individual qualifies to receive a social grant income. Prior to an individual being approved to receive the said social assistance, they are subjected to means testing. This requires that the SASSA evaluates their income as well as the assets of the applicants to determine whether or not their means are lower than the stipulated threshold amount. Should the applicant's assessment prove that their income and assets exceed the threshold set by the government, the applicant will not be eligible to receive the grant (SASSA, 2017, p. 7). Furthermore, if the applicant is married, SASSA conducts a means test on the combined incomes and assets of the applicant and their spouse (Black Sash, 2018).

\section{Types of social grants in South Africa}

The following types of social grants have been identified by the Department of Social Development (DSD) and describe the qualifying requirements for a recipient (Department of Social Development, 2017) and are listed in Table 1.

The objectives for the South African Social Security system as reflected in the Government's 1997 White Paper on Social Development are as follows:

\footnotetext{
...social security system is essential for healthy economic development, particularly in a rapidly changing economy, and will contribute actively to the development process. It is important for immediate alleviation of poverty and is a mechanism for active redistribution. (SASSA, 2017, p. 18)
}

An empirical study conducted by the DSD found that a reduction in poverty could be attributed to the financial assistance provided by government (Department of Social Development, 2015). Although social grants have been established to assist specific groups in need, it has been noted that unemployed or underpaid individuals within families tend to become dependent on the social grant beneficiaries' incomes and, as a result, hamper their own entrepreneurial drive (Sinyolo et al., 2017). Dependency on a social grant income discourages entrepreneurial development as the combined income of some grant recipients' households exceeded that of the income from their entrepreneurial activities (Sinyolo et al., 2017, p. 66). In a study by Rantanen, Pawlak and Toikko (2015), it was discovered that in a country like Poland, where the state is not expected to provide any form of social welfare, youth understand that the future lies in their hands and have confidence in their own abilities and skills to be entrepreneurs. The same study by Rantanen 
TABLE 1: Type of social grants and means test.

\begin{tabular}{|c|c|c|c|c|c|c|c|}
\hline \multirow[t]{3}{*}{ Social grant type } & \multirow[t]{3}{*}{ Purpose } & \multirow[t]{3}{*}{$\begin{array}{l}\text { Amount payable } \\
01 \text { October } 2018\end{array}$} & \multicolumn{4}{|c|}{$\begin{array}{l}\text { Means test (maximum income and assets to be } \\
\text { eligible for the grant) }\end{array}$} & \multirow{3}{*}{$\begin{array}{l}\text { Means test criteria for } \\
\text { South African Social } \\
\text { Security Agency Grants }\end{array}$} \\
\hline & & & \multicolumn{2}{|c|}{ Income } & \multicolumn{2}{|c|}{ Assets } & \\
\hline & & & Single & Married & Single & Married & \\
\hline $\begin{array}{l}\text { Care dependency } \\
\text { grant }\end{array}$ & $\begin{array}{l}\text { Income support to caregivers providing } \\
\text { permanent care to children with } \\
\text { severe mental or physical disabilities } \\
\text { (must submit a medical assessment). }\end{array}$ & R1700.00 & $\begin{array}{l}\text { R16 } 900 \mathrm{p} / \mathrm{m} \text { or } \\
\text { R202 } 800 \mathrm{p} / \mathrm{a}\end{array}$ & $\begin{array}{l}\text { R33 } 800 \mathrm{p} / \mathrm{m} \text { or } \\
\text { R405 } 600 \mathrm{p} / \mathrm{a}\end{array}$ & - & - & No asset test \\
\hline Child support grant & $\begin{array}{l}\text { Income support to caregivers or parents } \\
\text { of children in need. }\end{array}$ & R410.00 & $\begin{array}{l}\mathrm{R} 4000 \mathrm{p} / \mathrm{m} \text { or } \\
\mathrm{R} 48000 \mathrm{p} / \mathrm{a}\end{array}$ & $\begin{array}{l}\mathrm{R} 8000 \mathrm{p} / \mathrm{m} \text { or } \\
\mathrm{R} 96000 \mathrm{p} / \mathrm{a}\end{array}$ & - & - & No asset test \\
\hline Disability grant & $\begin{array}{l}\text { An income support measure given to } \\
\text { individuals who are either physically or } \\
\text { mentally disabled, unfit for formal } \\
\text { employment and are unable to care for } \\
\text { themselves. }\end{array}$ & R1700.00 & $\begin{array}{l}\text { R6510 p/m or } \\
\text { R78 } 120 \mathrm{p} / \mathrm{a}\end{array}$ & $\begin{array}{l}\text { R13 } 100 \mathrm{p} / \mathrm{m} \text { or } \\
\text { R157 } 200 \mathrm{p} / \mathrm{a}\end{array}$ & R1 115400 & R2 230800 & $\begin{array}{l}\text { Must submit a medical } \\
\text { or assessment report } \\
\text { confirming disability }\end{array}$ \\
\hline Foster care grant & $\begin{array}{l}\text { For persons who care for a child or } \\
\text { children who are not their own by birth } \\
\text { (must have a court order). }\end{array}$ & R960.00 & - & - & - & - & Not means tested \\
\hline $\begin{array}{l}\text { Grants for older } \\
\text { persons }\end{array}$ & $\begin{array}{l}\text { Income support for the elderly over the } \\
\text { age of } 60 \text {. }\end{array}$ & $\begin{array}{l}\text { R1700.00 } \\
\text { (R1720.00 if older } \\
\text { than } 75 \text { years) }\end{array}$ & $\begin{array}{l}\text { R6510 p/m or } \\
\text { R78 } 120 \mathrm{p} / \mathrm{a}\end{array}$ & $\begin{array}{l}\text { R13 } 100 \mathrm{p} / \mathrm{m} \text { or } \\
\text { R157 } 200 \mathrm{p} / \mathrm{a}\end{array}$ & R1 115400 & R2 230800 & - \\
\hline War veterans grant & $\begin{array}{l}\text { Income support for the individuals who } \\
\text { served in the I or II WW or the Korean War. }\end{array}$ & R1720.00 & $\begin{array}{l}\text { R6 } 510 \mathrm{p} / \mathrm{m} \text { or } \\
\text { R78 } 120 \mathrm{p} / \mathrm{a}\end{array}$ & $\begin{array}{l}\text { R13 } 100 \mathrm{p} / \mathrm{m} \text { or } \\
\text { R157 } 200 \mathrm{p} / \mathrm{a}\end{array}$ & R1 115400 & R2 230800 & - \\
\hline Grant in aid & $\begin{array}{l}\text { Income support to individuals (already } \\
\text { getting Older persons' Grant, War Veterans } \\
\text { or Disability Grant) who need full-time care } \\
\text { from someone. }\end{array}$ & R410.00 & - & - & - & - & Not means tested \\
\hline $\begin{array}{l}\text { Social relief of } \\
\text { distress grant }\end{array}$ & $\begin{array}{l}\text { Temporarily issued to individuals who are } \\
\text { in desperate need of income to provide for } \\
\text { the basic needs of their families. }\end{array}$ & Amount Varies & - & - & - & - & $\begin{array}{l}\text { No person receiving any } \\
\text { other grant may receive } \\
\text { the social relief of distress } \\
\text { grant simultaneously }\end{array}$ \\
\hline
\end{tabular}

Source: Adapted by authors from Black Sash. (2018). You and your rights: social grants April-September 2018. Retrieved from https://www.blacksash.org.za/images/yourrights/aprilseptember2018/ allEnglish2018.pdf

et al. (2015) discovered that youths in Finland have the knowledge of entrepreneurship but look for support from the state. The same youths depicted a lack of confidence in their own abilities to venture into entrepreneurship. This is an indication that dependency on state support affects the growth of entrepreneurship.

\section{Entrepreneurial behaviour}

The entrepreneurial orientation of an individual and their psychological characteristics as well as their willingness to engage in entrepreneurial activities are some of the influential traits that are used as predictors of EIs. An entrepreneur's psychological attributes and traits as well as their willingness to become an entrepreneur should ideally be positively related to their entrepreneurial start-up intentions and behaviours (Chatterjee \& Das, 2015). For purposes of this article, the motivation and proactiveness as well as the risk-taking propensity of social grant recipients form the basis of this study.

\section{Entrepreneurial intentions}

An individual's desire to embark on entrepreneurial activities could be influenced by their circumstantial limitations. There are numerous factors that can affect an individual's decision to become an entrepreneur: poverty, perception, entrepreneurial capabilities, peer pressure, identified opportunity and enabling environment (Chinyamurindi, 2016; Rantanen et al., 2015, p. 46). The EI of an individual is a desire for a career as an entrepreneur (Rantanen \& Toikko, 2014, p. 14). This notion is further developed by Kirkley (2016, p. 294) and Rantanen et al. (2015, p. 46) who state that EIs play a key role in fostering an individual's entrepreneurial behaviour. Figure 1 on the

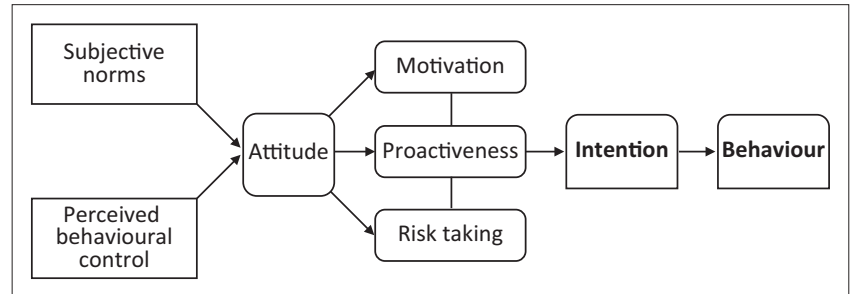

FIGURE 1: Structural diagram of the relationship between entrepreneurial intention and entrepreneurial behaviour.

following page is a diagrammatic representation of the relationship between EIs and entrepreneurial behaviour.

As illustrated in Figure 1, an individual's attitude (a combination of the individual's cognitive, affective and behavioural components) is influenced by subjective norms (individual's perceived social pressure to engage) and perceived behavioural control (the ease or difficulty with which an individual can perform a certain behaviour) (Ajzen, 1991). Furthermore, their intention to act in a certain way is perceived as encapsulating the motivational factor, which influences their rate of response to an identified opportunity (proactiveness) and how much effort an individual is willing to invest (risk taking propensity) to perform a certain behaviour. That is, the stronger the intention of an individual to behave in a certain manner towards a particular idea, the more likely it is that the behaviour will be manifested. The best indicator for an individual's behaviour is, in fact, their intention (Ajzen, 1991).

\section{The theory of planned behaviour}

Attitude: Ajzen (1991, p. 188) states that individuals develop their attitude based on the beliefs they have about the expected favourable or unfavourable outcome of the 
behaviour in question. In their study, Kusmintarti, Asdani and Riwajanti (2017, p. 30) describe entrepreneurial attitude as an evaluative behaviour, where an individual will decide whether or not to pursue certain opportunities and experience. An individual's entrepreneurial attitude, together with certain personality traits, might influence an individual's willingness to engage in entrepreneurial activities (Bolton \& Lane, 2012, p. 221).

Subjective norms: Lortie and Castogiovanni (2015, p. 938) describe subjective norms as the normative beliefs or attitudes considered by prospective entrepreneurs or individuals in relation to their families, friends or acquaintances regarding their approval or disproval of their intended behaviour. That is, in the case of entrepreneurship, other individuals have the ability to influence the intentions and behaviours of prospective entrepreneurs. It is, however, possible for external factors to positively influence a prospective entrepreneur's entrepreneurial development (Rueda, Moriano, \& Liñán, 2015, p. 63). As subjective norms reveal one's belief and confidence level (in this instance) of becoming an entrepreneur (Ajzen, 1991, p. 179), an individual's subjective norms are key in determining their EIs, which, in turn, are vital in fostering their entrepreneurial behaviour (Rantanen et al., 2015, p. 46).

Perceived behavioural control: Ajzen (1991, p. 179) describes the ease or difficulty with which an individual can perform certain behaviours based on their own perceptions of their abilities, as an individual's perceived behavioural control. That is, the confidence of a prospective entrepreneur, based on their own beliefs in their abilities, will influence their EI, accordingly encouraging them to pursue entrepreneurial opportunities (Kirkley, 2016, p. 320).

For purposes of this study, subjective norms as well as perceived behavioural control are summarised as 'attitude', which has an influential role in an individual's willingness to engage in entrepreneurial activities. This study will evaluate how the attitudes, influenced by subjective norms and the perceived behavioural control of social grant recipients, will affect their motivation to engage in entrepreneurial activities and their risk-taking propensity as well as their proactiveness.

Scholars have previously highlighted the importance of entrepreneurial orientation and the key role played by factors such as motivation, proactiveness and risk taking in stimulating entrepreneurial propensities and determining EI (Ibrahim \& Mas'ud, 2016, p. 228; Koe, 2016, p. 3; Kirkley, 2016, p. 320; Yan \& Ologundudu).

\section{Hypothesis}

To venture into entrepreneurship requires a set of strong psychological beliefs which act as motivators to work towards entrepreneurial self-identity (Kirkley, 2016, p. 320). The need for achievement (motivation) underpinned by entrepreneurial education is a key factor in being proactive and taking of risks to start something which is unique (Chen, Su, \& Wu, 2012, p. 1316).

Risk taking: Risk taking is part of entrepreneurship and it distinguishes entrepreneurs from non-entrepreneurs. An entrepreneur takes risks to achieve the desired success (Chatterjee \& Das, 2015). Some studies have shown that countries with high social economic equality have the tendency to influence individuals with risk-taking propensity to postpone their entrepreneurship intention (Antoncic et al., 2018; Crant, 1996). For EIs to be realised, an individual must be motivated to start and manage a business. This passion (motivation) will enable the entrepreneur to be proactive in identifying opportunities in the business environment and be ready to take calculated risks for the expected returns associated with the identified opportunities (BarbaSánchez \& Atienza-Sahuquillo, 2017; Ismail et al., 2016).

Given these arguments, the first hypothesis was formulated:

H1: There is a statistically significant difference between respondents with a high-risk propensity, with reference to their intention to start a business, if social grants are cancelled.

Motivation: Minimal research has been performed for the relationship that exists between the social grant system and entrepreneurship. Social grants have been found to have a positive influence on household welfare, with a considerably greater positive effect on women than on men (Biyase, 2018). A study by Surender et al. (2010, pp. 216-218) found that grant recipients in South Africa do not succumb to a dependency culture, but have the same aspirations and attitudes found in non-recipients. The recipients are willing to accept low paying jobs as a platform from which to improve their lives. A higher proportion of employers and employed individuals support the extension of grants to the unemployed to leverage their chance of finding employment (Mtembu \& Govender, 2015). There is also further indication that social grant recipients use a portion of their grant income responsibly to alleviate financial constraints in their entrepreneurial venture (Sinyolo et al., 2017, p. 233).

On the other hand, it has been found that there are several individuals in impoverished geographical areas who do not value paid work and are satisfied to receive their income from government cash transfers. The concluding view is that the existing grants may weaken work motivation as well as create a dependency culture amongst the said grant recipients and would effectively perpetuate poverty and not alleviate it (Surender et al., 2010, p. 205).

Chen et al. (2012, p. 131) found that motivation is underpinned by entrepreneurial education. That is, individuals would be more willing to take risks as well as engage in entrepreneurial behaviour if they have been exposed to entrepreneurial education. Entrepreneurial motivation includes inspiration factors behind becoming entrepreneur. It combines the willingness (influenced by perception) a person has for entrepreneurship and the 
abilities (experience) to start their own business (BarbaSánchez \& Atienza-Sahuquillo, 2017; Chatterjee \& Das, 2015; Farhangmehr, Gonçalves, \& Sarmento, 2016).

The second hypothesis was based on the views stated above:

H2: There is a statistically significant difference between respondents with a high level of motivation with reference to their intention to start a business if social grants are cancelled.

Proactiveness: Proactiveness (propensity to act) represents entrepreneurial alertness and presents a stronger inclination towards EIs. Proactiveness helps the individual to identify opportunities present in the business environment to enable the establishing and managing of a venture (Awang, Amran, Nor, Ibrahim, \& Razali, 2016; Crant, 1996; Haider, Asad, \& Fatima, 2017; Karabulut, 2016). It can be concluded that the EIs of social grant recipients may be influenced by their entrepreneurial abilities and ambitions to identify opportunity and have the propensity to act. This led to the development of the third hypothesis, which was to investigate the following:

H3: There is a statistically significant difference between respondents with high levels of proactiveness with reference to their intention to start a business, if social grants are cancelled.

A higher entrepreneurial proactiveness is prevalent in individuals who are highly motivated and who interact with others to obtain support and encouragement (Zeffane, 2013). The more creative and self-confident an individual is, the more likely they are to take risks and venture into entrepreneurship to achieve the desired target (Nasip, Amirul, Sondoh, \& Tanakinjal, 2017, p. 834). Creating employment through entrepreneurship is part of the economic development strategy of the South African government to reduce the levels of unemployment and alleviate poverty (Malebana, 2017). The main objective of this study was to investigate the EIs of the social grant beneficiaries in Johannesburg and Tshwane. Therefore, the study sought to determine the extent to which the social grant beneficiaries desire and plan to embark on entrepreneurial activities, in that they do receive some form of financial aid.

The objectives of this study were:

- to investigate the motivation of social grant recipients towards a career in entrepreneurship

- to investigate how social grant income influences the EIs of unemployed youth who are beneficiaries of the scheme

- to establish the likelihood of unemployed people developing EIs in the absence of a social grant income

- provide practical solutions for policy-makers to enable them to create entrepreneurial support structures that can ensure that South African entrepreneurial initiatives are a success.

Based on the above discussion, the study sought to establish, within a South African context, the extent to which the EIs of social grant beneficiaries were influenced by their direct or indirect benefit from a social grant income.

\section{Methodology}

\section{Sampling}

Target population and units of analysis: The target population for this study consisted of direct and indirect recipients of social grant funds in various locations within the cities of Johannesburg and Tshwane. Direct social grant recipients are those who are registered to personally receive social grant income, whereas indirect social grant recipients are those who benefit financially from social grant income through one or more of their family members. The units of analysis were social grant recipients ranging between the ages of $18-75$, receiving either one or more of the available of social grants types. The data were collected directly from the participants at SASSA and South African Post Office (SAPO) pay points. The questionnaires were distributed to social grant beneficiaries who were randomly selected while waiting for services at SASSA pay points and offices.

\section{Data collection}

\section{Survey method}

Data for the main study were collected over a 2-month period during September and October 2018, when participants were approached at the various SASSA pay points and SAPO branches. The information was obtained directly from the recipients through their responses on the paper-based questionnaires and a total of 401 completed questionnaires were returned by the sampled social grant recipients. The targeted group was made up of 201 respondents in the City of Johannesburg and 200 in the City of Tshwane. The resulting sample can be described as a purposive sample.

\section{Measurement}

\section{Demographic variable}

The questionnaire included questions on gender, age, home language and level of education. Nominal scales were used for gender, language and education level. An interval scale was used to gather data for age and single response questions were used for gender, home language and highest education level. These variables were tested with four items in the questionnaire.

\section{Social grant survey}

The study utilised a progression approach from the nominal scale, interval scales to ordinal scales for measurement. Eleven items tested this variable. This part of the survey sought to determine the number of dependants per household, the type of grants received and the average income derived from grants per household. A mix of singlechoice and multiple-choice questions was used for grants received. Likert scales graded: 1 - Strongly Agree, 2 - Agree, 3 - Neither Agree or Disagree, 4 - Disagree and 5 - Strongly Disagree, were used to gather data on the recipient's 
perception regarding the importance of social grants to South Africa. The questions covered the prospects of families surviving without grants, provision of grants for the unemployed and alleged misuse of grants by some recipients. The respondents were also investigated concerning whether social grants have an influence on the EIs of the youth. The key question in this section was: 'Would you start a business if you were not receiving a social grant?'

\section{Entrepreneurial intention}

In this part of the questionnaire, the study mainly utilised ordinal scales: a five-point Likert scale was used. It was graded: 1 - Strongly Agree, 2 - Agree, 3 - Neither Agree or Disagree, 4 - Disagree and 5 - Strongly Disagree. The 39 items that were derived from the literature and previous publications in this section had to be separately rated by respondents. The main aim of this section was to study the respondents' level of motivation, proactiveness and risk taking.

\section{Analysis}

For the purpose of this research, a factor analysis was conducted to determine the stability of the applicable constructs. This was followed by the analysis of the demographic data and concluded with a more detailed analysis by conducting an analysis of variance (ANOVA). The results of the factor analysis yielded high loadings and, for the purpose of this research, it was decided that just three factors should be included: risk taking (eigenvalue of 9.027 and a variance of $24.4 \%$ explained), motivation (eigenvalue of 4.94 and a variance of $13.34 \%$ explained) and proactiveness (eigenvalue of 2.71 and a variance of $7.32 \%$ explained). This served as an indication that the factor structure was stable with a significance of 0.000 and it was therefore deduced that the questionnaire was valid.

\section{Ethical consideration}

This article followed all ethical standards for carrying out research, approved by the Department of Business Management at the University of Pretoria, South Africa. A letter of permission received from an Executive Manager in the Grants Administration Department at SASSA was issued to the researchers, permitting them to conduct their research. This permission letter was presented to the managers at the local SASSA office and SAPO branches prior to data collection at their premises. Upon permission being granted to conduct the data collection at the SASSA local offices and SAPO branches, the respondents were given an informed consent form. The form explained the purpose of the study, indicated that participation in the study was voluntary and that the respondent could at any point withdraw from the activity of filling out the questionnaire. In addition to this, the form provided assurances of anonymity and confidentiality. The participants were only given a questionnaire after they had signed the consent form.

\section{Results \\ Descriptive statistics}

The IBM Statistical Package for the Social Sciences ${ }^{\mathrm{TM}}$ (SPSS) Version 25 was used to analyse all the data gathered during the research.

\section{Demographics and social grants survey}

Of the 401 respondents surveyed, $74 \%$ were female and $26 \%$ were male. The largest percentage of respondents of $70 \%$ were aged between 18 and 40 years. Just $6 \%$ of the group was aged below 18 years. This correlates with the finding that child support grant is the largest expenditure disbursed to recipients.

\section{Social grants survey}

The findings as presented in Figure 2 regarding the marital status of respondents show that $75 \%$ of the recipients indicated that they had never married.

A total of $80.5 \%$ of the respondents had less than five dependants per household. Two respondents $(0.5 \%)$ stated a total of more than 10 dependants per household. The most prevalent monthly income derived from social grants ranged between R1000 and R5000, with this category being the most common for $56 \%$ of the respondents. Just $5 \%$ of the respondents derived income from social grants of between R5000 and R10 000. When it came to the benefits provided by the social security system, 51\% of the respondents strongly agreed with the statement that 'social grants support poor families in daily survival' followed by $33 \%$ of respondents who also agreed. This effectively indicates that $84 \%$ of the respondents believe that social grants support poor families in their daily struggle for survival. However, most of the respondents acknowledged that the income was not adequate. This response had not been included in the questionnaire. Figure 3 illustrates combined household incomes.

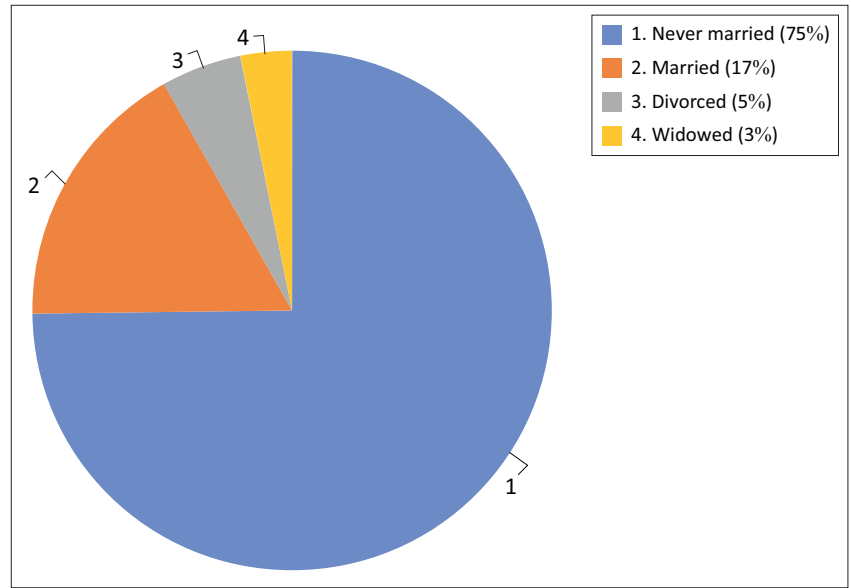

FIGURE 2: Marital status. 
The findings presented in Figure 3 regarding the combined household income received from social grants indicated that most households received a combined income of between R1000 and R5000 per month, followed by households receiving less than R1000 per month. With reference to Table 1 (means test), the total combined income is not considered as the only income of the recipients and they may still qualify, although they receive other forms of income; but for the purpose of this research, just the grant income was considered to be of relevance. There may be the possibility of additional income from certain households, and this study does not claim that the only income received is from SASSA holders.

Fifty-six per cent disagreed with the statement that South Africans can survive without social grants. On the question of social grants being sometimes misused by recipients, $72 \%$ agreed with the statement.

A mixed response was also received on the question on the relationship between social grants and entrepreneurship. When respondents were asked whether social grants discourage youth from starting a business, 44\% disagreed with the statement. When a contrary statement was posed on whether social grants encourage youth to start businesses, a mixed response was received with $32 \%$ undecided, while $37 \%$ disagreed with the statement and $31 \%$ agreeing with it. The uncertainty was also evident when respondents were asked to rate the statement that 'there is no relationship between social grants and youth entrepreneurship'.

On the question of whether the respondents would start a business if they were not receiving social grants, Figure 4 graphically represents the responses received.

The findings presented in Figure 4 regarding the willingness of social grant beneficiaries to start a business in the absence of a social grant income indicated that $67 \%$ of the respondents were prepared to start a business if they received no grant income. However, $33 \%$ of the respondents indicated that they were not prepared to start a business even in the

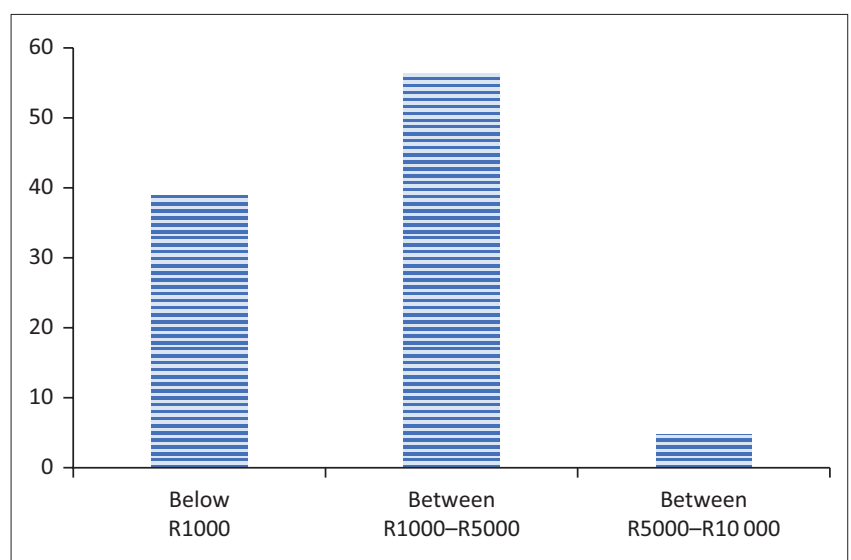

FIGURE 3: Combined household income. absence of social grant income. In the broader perspective, given that 17.6 million beneficiaries receive grants, there are approximately 5.8 million beneficiaries who would not be prepared to start a business.

\section{Analysis of variance}

To analyse whether the differences between those respondents who indicated that they would start businesses if they did not receive a grant anymore, it was decided to test whether there are statistically significant differences between the diverse variables of the three constructs of EI: motivation, risk orientation and proactiveness. These findings have to be placed in context, given the fact that the probability of social grants being cancelled is very low. The improbability of social grants being cancelled may have influenced the responses from the respondents. Table 2 reports the results of the ANOVA test on risk taking and the absence of social grants.

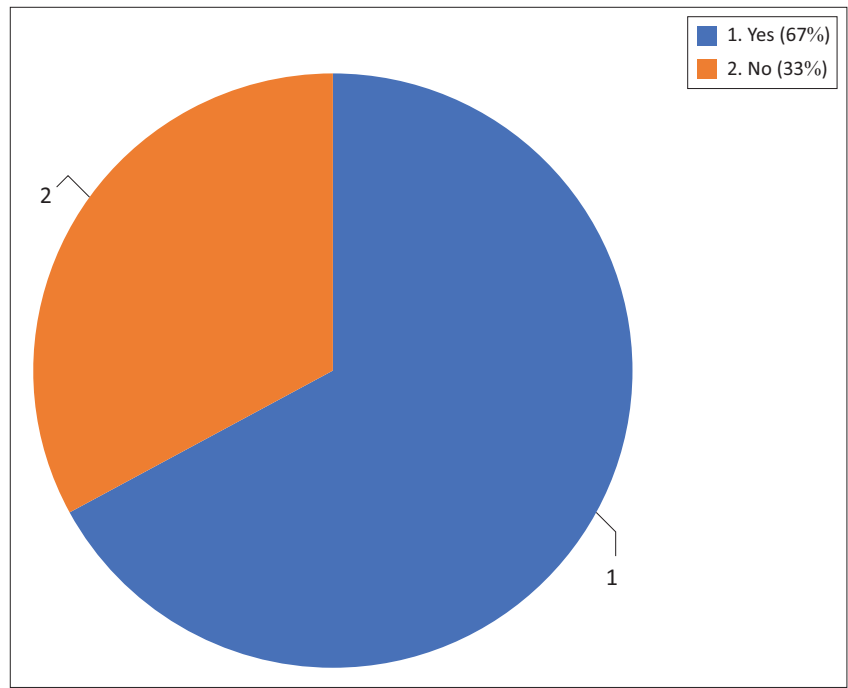

FIGURE 4: Willingness to start a business in the absence of grant income.

TABLE 2: Analysis of variance test on risk taking versus starting a business in the absence of social grant income.

\begin{tabular}{lccccc}
\hline Variable & $\begin{array}{c}\text { Sum of } \\
\text { squares }\end{array}$ & $d f$ & $\begin{array}{c}\text { Mean } \\
\text { square }\end{array}$ & $F$ & Significance \\
\hline Willing to take risks & 9.706 & 1 & 9.706 & 10.404 & $0.001^{* *}$ \\
\hline $\begin{array}{l}\text { Take bold action by venturing } \\
\text { into unknown }\end{array}$ & 7.247 & 1 & 7.247 & 6.508 & $0.011^{*}$ \\
$\begin{array}{l}\text { Not concerned about } \\
\text { probability of failure }\end{array}$ & 9.463 & 1 & 9.463 & 6.614 & $0.010^{*}$ \\
$\begin{array}{l}\text { Strong tendency of high-risk } \\
\text { projects }\end{array}$ & 20.512 & 1 & 20.512 & 16.184 & $0.000^{* *}$ \\
$\begin{array}{l}\text { Belief in taking bold new } \\
\text { action is necessary }\end{array}$ & 21.361 & 1 & 21.361 & 24.992 & $0.000^{* *}$ \\
$\begin{array}{l}\text { Willingness to use own } \\
\text { money }\end{array}$ & 46.774 & 1 & 46.774 & 34.401 & $0.000^{* *}$ \\
$\begin{array}{l}\text { Willingness to risk reputation } \\
\text { in business failure }\end{array}$ & 17.050 & 1 & 17.050 & 12.214 & $0.001^{* *}$ \\
$\begin{array}{l}\text { Willingness to lose money in } \\
\text { business failure }\end{array}$ & 42.681 & 1 & 42.681 & 32.270 & $0.000^{* *}$ \\
$\begin{array}{l}\text { Take bold aggressive steps in } \\
\text { decision-making }\end{array}$ & 12.180 & 1 & 12.180 & 12.250 & $0.001^{* *}$ \\
$\begin{array}{l}\text { Take bold aggressive steps } \\
\text { exploiting opportunities }\end{array}$ & 11.570 & 1 & 11.570 & 12.556 & $0.000^{*}$ \\
\hline
\end{tabular}

*, indicates a statistical significant variance at $\alpha=0.05$, confidence interval: $95 \%$; $* *$, indicates a statistical significant variance $\alpha=0.001$ with $99 \%$ confidence interval. 
As indicated in Table 2, there are a number of significant differences between the responses of those who are prepared to start a business and those who would not contemplate doing so, even if the social grant were to be removed. The least significant differences are the variables about venturing into the unknown and concern about the probability of failure. All other variables differ on an $\alpha$-level $=0.001$ on a confidence level of $99 \%$. In summary, it was very clear that the risk-taking propensity of almost $40 \%$ of these respondents, even if social grants were to be cancelled, would influence their EI.

Motivation is very important for entrepreneurial behaviour. In Table 3, it is very clear how significant the differences between these groups are. Once again, with a very high level of accuracy ( $\alpha=0.001$ with $99 \%$ confidence interval), almost $40 \%$ of the sample indicated that they are not willing to partner in business, they are not currently engaged in any activity aimed at starting a business, they were not interested in starting a business within the next $3-5$ years, they did not plan on starting a business after completing school, did not plan to start a business, had no desire to start a business, did not have a strong desire to own a business, were not attracted to the idea of starting their own business and would not start a business within the next 10 years.

In Table 4, the proactiveness of social grant recipients is compared with their ability to start a business. Proactiveness is a fundamental element of entrepreneurial intensity. The two groups differ highly significantly on just two variables: always have a solution to future problems versus immediate gratification. This seemed doubtful to the researchers as one would expect the same number of significant differences to have been found between the two groups who were prepared to start a business and those who are not willing to do so. However, as indicated by the two significant differences, solutions to future problems are clearly an indication that those respondents who indicated that they were not interested in starting a business in the absence of a social grant income also do not always have solutions to their future needs. Another significant difference was the issue of immediate gratification, regarding which it was found that the age group 18-30 measures the highest on this specific variable. Given that an entrepreneurial career requires a long-term vision, persistence and perseverance, this is clearly indicative of the difference in lack of entrepreneurial intensity between the respondents who indicated that they would start a business in the absence of social grant income and those who indicated that they were not prepared to do so.

\section{Hypotheses}

\section{Hypothesis 1}

H1: There is a statistically significant difference between respondents with a high-risk propensity with reference to their intention to start a business if social grants are cancelled.

$\mathrm{H} 1$ is accepted as there are significant differences as indicated in Table 2.
TABLE 3: Analysis of variance test on motivation versus starting a business in the absence of social grant income.

\begin{tabular}{|c|c|c|c|c|c|}
\hline Variable & $\begin{array}{l}\text { Sum of } \\
\text { Squares }\end{array}$ & $d f$ & $\begin{array}{l}\text { Mean } \\
\text { square }\end{array}$ & $F$ & Significance \\
\hline Willingness to partner in business & 34.057 & 1 & 34.057 & 25.396 & $0.000 * *$ \\
\hline $\begin{array}{l}\text { Currently engaged in activity to start } \\
\text { a business within } 12 \text { months }\end{array}$ & 33.637 & 1 & 33.637 & 24.121 & $0.000 * *$ \\
\hline Willing to start business in $3-5$ years & 53.066 & 1 & 53.066 & 39.989 & $0.000 * *$ \\
\hline $\begin{array}{l}\text { Plan to start business after completing } \\
\text { school }\end{array}$ & 25.503 & 1 & 25.503 & 16.507 & $0.000 * *$ \\
\hline Do not plan to start a business & 51.445 & 1 & 51.445 & 32.336 & $0.000 * *$ \\
\hline Desire to be self-employed & 54.313 & 1 & 54.313 & 40.881 & $0.000 * *$ \\
\hline Consider myself to be entrepreneurial & 51.860 & 1 & 51.860 & 39.252 & $0.000 * *$ \\
\hline Strong desire to own my business & 73.995 & 1 & 73.995 & 56.797 & $0.000 * *$ \\
\hline Starting my business an attractive idea & 47.560 & 1 & 47.560 & 37.810 & $0.000 * *$ \\
\hline I will start business in the next 10 years & 14.788 & 1 & 14.788 & 8.430 & $0.004 *$ \\
\hline
\end{tabular}

TABLE 4: Analysis of variance test on proactiveness versus starting a business in the absence of social grant income.

\begin{tabular}{lccccc}
\hline Variable & $\begin{array}{l}\text { Sum of } \\
\text { squares }\end{array}$ & $d f$ & $\begin{array}{c}\text { Mean } \\
\text { square }\end{array}$ & $F$ & Significance \\
\hline I set realistic goals & 0.174 & 1 & 0.174 & 0.242 & 0.623 \\
$\begin{array}{l}\text { I am proactive and plan } \\
\text { ahead }\end{array}$ & 2.131 & 1 & 2.131 & 3.049 & 0.082 \\
$\begin{array}{l}\text { I prefer to take charge to } \\
\text { get things going }\end{array}$ & 1.566 & 1 & 1.566 & 2.117 & 0.146 \\
$\begin{array}{l}\text { Always have solution to } \\
\text { future problems }\end{array}$ & 12.781 & 1 & 12.781 & 13.158 & $0.000^{* * *}$ \\
$\begin{array}{l}\text { Always try new and unusual } \\
\text { activities }\end{array}$ & 3.060 & 1 & 3.060 & 3.220 & 0.074 \\
$\begin{array}{l}\text { Do not know how to set } \\
\text { goals }\end{array}$ & 2.181 & 1 & 2.181 & 1.764 & 0.185 \\
$\begin{array}{l}\text { I do not plan ahead } \\
\begin{array}{l}\text { I do not have patience to } \\
\text { set goals }\end{array}\end{array}$ & 0.013 & 1 & 0.013 & 0.012 & 0.911 \\
\hline \begin{tabular}{l} 
I want things instantly \\
\hline
\end{tabular} & 8.124 & 1 & 0.167 & 0.126 & 0.723 \\
\hline
\end{tabular}

* indicates a statistical significant variance at $\alpha=0.05$, confidence interval: $95 \% \cdot * *$ indicates a statistical significant variance $\alpha=0.001$ with $99 \%$ confidence interval.

\section{Hypothesis 2}

H2: There is a statistically significant difference between respondents with high levels of motivation with reference to their intention to start a business if social grants are cancelled.

$\mathrm{H} 2$ is accepted as there are significant differences as indicated in Table 3.

\section{Hypothesis 3}

H3: There is a statistically significant difference between respondents with high levels of proactiveness with reference to their intention to start a business if social grants are cancelled.

$\mathrm{H} 3$ is accepted as there are significant differences as indicated in Table 4.

\section{Discussion}

\section{Summary of findings and conclusion}

The high levels of unemployment in South Africa have a direct impact on the demand for certain social grants, such as the Child Support grant. Most of the survey respondents 
were women, indicating that the social grant recipient population is predominantly women. It was also evident that most recipient households are either headed by children or single parents as approximately $75 \%$ of the respondents have never been married. Respondents also overwhelmingly agreed that social grants are a necessity in South Africa and that the poor cannot do without them. The indecision shown when it comes to rating social grant influence on entrepreneurship demonstrates that the social grants have become a part of the recipients' lives and that it is difficult to find alternative sources of income. The Small Enterprise Development Agency (2016) stated that entrepreneurial activities will most likely increase economic efficiencies through innovation and growth, job creation and, as a result, reduce unemployment levels. Unless entrepreneurship is brought to their attention and the benefits derived are made visible, most recipients will remain dependent on the social grant system and not use it as a leverage to get out of poverty. Thirty-three per cent of the respondents stated that they have no intention of starting a business in the absence of social grants. Ironically, this percentage of respondents is almost equivalent to the percentage of social grant recipients to the population of South Africa. It should, however, be noted that $67 \%$ of the respondents who stated that they would start a business were also aware that social grants would not be readily discontinued.

A lack of knowledge regarding the existing Small, Micro and Medium Enterprises (SMME) support organisations created by the government to promote entrepreneurship was prevalent. Responses to this question saw the Small Business Development Department to manage a highest score of the findings of just below $16 \%$. This percentage occurs in the middle age group of between 41 and 50 years of age. When compared with the youth, the 41-40 age group was also surprisingly the group who were most familiar with the majority of small business support organisations in South Africa. This is a signal to policy makers that social grant recipients, predominantly the youth, do not have adequate exposure to entrepreneurship as an alternative to poverty alleviation. Appropriate focus is required to target entrepreneurial education of the potential recipients and expose them to the available support environments.

\section{Managerial recommendations}

As was mentioned, the South African Constitution, Section 27 (1)(c), states '...everyone has the right to have access to ... social security, ... if they are unable to support themselves and their dependants...' (South Africa, 1996). In addition to this, studies have indicated that there is a need for social welfare systems to alleviate poverty. Notwithstanding the above, and based on the findings, it was concluded that a dependency on social grant income is created amongst the grant recipients, as entrepreneurial knowledge is not widespread amongst them nor has it been effectively promoted to those recipients surveyed, as an alternative means of poverty alleviation. It would be unfair to suggest that social grant funding be stopped. Therefore, the recommendation of this study is that grant funding be administered differently. The social grants should be viewed as a short-term solution and it is consequently further recommended that policy makers revise and amend some of their pre-conditions for young applicants. The means test should not be the sole determinant in the consideration of issuing grants to applicants.

It is also important to note while that large sums of money are currently being invested into start-up developmental programmes, as well as governmental institutions (Small enterprise development Agency [SEDA], Small Enterprise Finance Agency [SEFA], National Youth Development Agency [NYDA], Sector Education and Training Authorities [SETA] and so forth), very few of the study participants were aware of these opportunities. In its youth empowerment drives, the DSD should join forces with the Department of Small Business and private sector entrepreneurship support structures to educate recipients on the benefits of entrepreneurship. An exit plan for the beneficiaries prior to the expiry of the grants should be instituted in order to eliminate recipient dependency as well as administrative corruption so that a smooth transition into entrepreneurship can be realised. This study further recommends that policy makers educate and train the upcoming generation at grassroots level to be proactive and risk takers and not rely on safe employment only. The objective will be to instil a culture of entrepreneurship that creates businesses that grow and to eliminate dependency on the state. Employment opportunities will increase as businesses are created and ultimately lead to the growth of the economy (Small Enterprise Development Agency, 2016).

\section{Limitations and recommendations for future research}

While undertaking data collection, it became evident that some of the respondents were not familiar with certain entrepreneurial terms of the questionnaire. As a result, the researchers had to verbally explain the questions to the participants to increase the validity of the response. The study was limited to the cities of Johannesburg and Tshwane.

As the research was mainly located in Gauteng, further studies could be undertaken in other provinces to establish a comparison on the extent to which social grants influence the EI of the recipients in the other provinces. Moreover, research could also investigate how the social grant expenditure, which is expected to have reached over R500 billion by 2020 (The National Treasury of South Africa, 2018), could be optimally utilised so that it supports the disadvantaged in society. The social grant expenditure also becomes an opportunity for the growth of a unique type of entrepreneurship amongst the youth recipients.

The use of the means tests by SASSA on recipients as a criterion to access social grants requires further examination 
of the capability of this method to effectively assess eligibility, detect non-compliance and eliminate manipulation.

On the one hand, this study has indicated that the social grant could be the sole lifeline for one group of recipients, while, on the other hand, social grants could be a leverage to entrepreneurship on another group of recipients. As the largest recipient group of these grants are youths, a further examination of the entire system may enable the core objectives of poverty alleviation to be optimally achieved, eliminating dependency. The entrepreneurial potential of a unique social grant system that integrates a continuous entrepreneurial education and support for the potential recipients is an area for further investigation.

\section{Acknowledgements}

The authors would like to thank all the participants who took part in this study. We would like also to extend our gratitude to the language editors, the reviewers and the publishing editor for their comments and suggestions that has formed part of this article.

\section{Competing interests}

The authors have declared that no competing interest exist.

\section{Authors' contributions}

All authors contributed equally to this work.

\section{Funding information}

This research received no specific grant from any funding agency in the public, commercial or not-forprofit sectors.

\section{Data availability statement}

The data that support the findings of this study are available from the corresponding author, J.P., upon reasonable request.

\section{Disclaimer}

The views and opinions expressed in this article are those of the authors and do not necessarily reflect the official policy or position of any affiliated agency of the authors.

\section{References}

Ajzen, I. (1991). The theory of planned behavior. Organizational Behavior and Human Decision Processes, 50(2), 179-211. https://doi.org/10.1016/07495978(91)-T

Antoncic, J.A., Antoncic, B., Gantar, M., Hisrich, R.D., Marks, L.J., Bachkirov, A.A., .. Coelho, A. (2018). Risk-taking propensity and entrepreneurship: The role of power distance. Journal of Enterprising Culture, 26(01), 1-26. https://doi.org/10.1142/ S0218495818500012

Awang, A., Amran, S., Nor, M.N.M., Ibrahim, I.I., \& Razali, M.F.M. (2016). Individual entrepreneurial orientation impact on entrepreneurial intention: Intervening effect of PBC and subjective norm. Journal of Entrepreneurship, Business and Economics, 4(2), 94-129.

Barba-Sánchez, V., \& Atienza-Sahuquillo, C. (2017). Entrepreneurial motivation and self-employment: Evidence from expectancy theory. International Entrepreneurship and Management Journal, 13(4), 1097-1115. https://doi.org/10.1007/s11365017-0441-z
Bengtsson, N. (2010). The marginal propensity to earn, consume and save out of unearned income in South Africa. Uppsala: Department of Economics, Uppsala University.

Biyase, M. (2018). Assessing the impact of social grants on household welfare using morning after simulation and PSM approach. MPRA Paper 84477. University Library of Munich, Munich.

Black Sash. (2018). You and your rights: social grants April-September 2018. Retrieved from https://www.blacksash.org.za/images/yourrights/aprilseptember2018/ allEnglish2018.pdf

Bolton, D.L., \& Lane, M.D. (2012). Individual entrepreneurial orientation: Development of a measurement instrument. Education and Training, 54(2-3), 219-233.

Brière, S., Tremblay, M., \& Daou, A. (2014). Entrepreneurship in South Africa: Looking beyond funding. Development and Learning in Organizations, 28(2), 17-19. https://doi.org/10.1108/DLO-08-2013-0052

Chatterjee, N., \& Das, N. (2015). Key psychological factors as predictors of entrepreneurial success: A conceptual framework. Academy of Entrepreneurship Journal, 21(1), 102.

Chen, S., Su, X., \& Wu, S. (2012). Need for achievement, education, and entrepreneurial risk-taking behavior. Social Behavior and Personality: An International Journal, 40(8), 1311-1318. https://doi.org/10.2224/sbp.2012.40.8.1311

Chinyamurindi, W.T. (2016). A narrative investigation on the motivation to become an entrepreneur among a sample of black entrepreneurs in South Africa: Implications for entrepreneurship career development education. Acta Commercii, 16(1), 1-9.

Chowdhury, F., Desai, S., \& Audretsch, D.B. (2018). The grand challenges of social welfare. In Corruption, entrepreneurship, and social welfare (pp. 9-21). Cham: Springer.

City Press. (2011). Social grants can't be sustained. City Press. Retrieved from https:// www.news24.com/Archives/City-Press/Social-grants-cant-be-sustainedZuma-20150430

Crant, J.M. (1996). The proactive personality scale as a predictor of entrepreneurial intentions. Journal of Small Business Management, 34(3), 42-49.

Department of Social Development. (2013). Framework for social welafare services. Retrieved from www.dsd.gov.za/index2.php?option=com_docman\&task=doc view\&gid $=515 \&$ ltemid $=19$

Department of Social Development. (2015). Strategic Plan 2015 - 2020. Retrieved from http://www.dsd.gov.za/index2.php?option=com docman\&task=doc view\&gid= 598\&/temid=3

Department of Social Development. (2017). Social grants. Retrieved from http:// www.sassa.gov.za/index.php/social-grants

Department of Social Development. (2018). Fact sheet: Issue No.21 - September 2018. A statistical summary of social grants in South Africa. Retrieved from file:///C:/Users/johnp/Downloads/fact $\% 20$ sheet $\% 20$ for $\% 20$ september $\% 20$ 2018\%20(1).pdf

Farhangmehr, M., Gonçalves, P., \& Sarmento, M. (2016). Predicting entrepreneuria motivation among university students: The role of entrepreneurship education. Education+ Training, 58(7/8), 861-881. https://doi.org/10.1108/ET-01-2016-0019

Groenmeyer, S. (2016). The political dynamics of the adoption and extension of child support grants. Transformation: Critical Perspectives on Southern Africa, 91(1), 136-156.

Haider, S.H., Asad, M., \& Fatima, M. (2017). Entrepreneurial orientation and business performance of manufacturing sector small and medium scale enterprises of Punjab Pakistan. European Business and Management, 3(2), 21-28. https://doi org/10.11648/j.ebm.20170302.12

Hall, K. (2010). Income poverty, unemployment and social grants: Children's Institute, University of Cape Town, Cape Town.

Ibrahim, N.A., \& Mas'ud, A. (2016). Moderating role of entrepreneurial orientation on the relationship between entrepreneurial skills, environmental factors and on the relationship between entrepreneurial skills, environmental factors and 225-236. https://doi.org/10.5267/j.msl.2016.1.005

Ismail, I., Husin, N., Rahim, N.A., Kamal, M.H.M., \& Mat, R.C. (2016). Entrepreneurial success among single mothers: The role of motivation and passion. Procedia Economics and Finance, 37(16), 121-128. https://doi.org/10.1016/S2212-5671(16)30102-2

Karabulut, A.T. (2016). Personality traits on entrepreneurial intention. Procedia-Social and Behavioral Sciences, 229, 12-21.

Khuong, M.N., \& An, N.H. (2016). The factors affecting entrepreneurial intention of the students of Vietnam National University: A mediation analysis of perception toward entrepreneurship. Journal of Economics, Business and Management, 4(2), 104-111. https://doi.org/10.7763/JOEBM.2016.V4.375

Kirkley, W.W. (2016). Entrepreneurial behaviour: The role of values. Internationa Journal of Entrepreneurial Behavior \& Research, 22(3), 290-328.

Koe, W. (2016). The relationship between individual entrepreneurial orientation (IEO) and entrepreneurial intention. Journal of Global Entrepreneurship Research, 6(13), 1-11.

Kusmintarti, A., Asdani, A., \& Riwajanti, N.I. (2017). The relationship between creativity, entrepreneurial attitude and entrepreneurial intention (Case study on the students of State Polytechnic Malang). International Journal of Trade and Global Markets, 10(1), 28-36. https://doi.org/10.1504/IJTGM.2017.082379

Lortie, J., \& Castogiovanni, G. (2015). The theory of planned behavior in entrepreneurship research: What we know and future directions. International Entrepreneurship and Management Journal, 11(4), 935-957.

Mabugu, R., Chitiga, M., Fofana, I., Abidoye, B., \& Mbanda, V. (2014). Assessing the general equilibrium effects of social grants in South Africa. In 17th Annual general equilibrium effects of social grants in South Africa. In 17th Annual
Conference on Global Economic Analysis, Dakar, Senegal, Purdue University, West Lafayette, In: Global Trade Analysis Project (GTAP). pp. 18-20. Retrieved from https://www.gtap.agecon.purdue.edu/resources/res_display. asp? RecordID $=4539$ 
Malebana, M.J. (2017). Knowledge of entrepreneurial support and entrepreneurial intention in the rural provinces of South Africa. Development Southern Africa, 34(1), 74-89. https://doi.org/10.1080/0376835X.2016.1259990

Mbeki, T. (2007). State of the Nation address of the President of South Africa. Retrieved from https://www.gov.za/node/538254

Mitileni, M., \& Sithole, S. (2016). Three worlds of welfare, capitalism and social services: A case of South Africa. South African Association of Public Administration and Management (SAAPAM), 246-254.

Mtembu, V.N., \& Govender, L.N. (2015). Perceptions of employers and unemployed youth on the proposed youth employment wage subsidy incentive in South Africa: A KwaZulu-Natal study. SA Journal of Human Resource Management, 13(1), 1-9. https://doi.org/10.4102/sajhrm.v13i1.653

Nasip, S., Amirul, S.R., Sondoh, Jr. S.L., \& Tanakinjal, G.H. (2017). Psychological characteristics and entrepreneurial intention: A study among university students in North Borneo, Malaysia. Education+ Training, 59(7/8), 825-840.

Rantanen, T., \& Toikko, T. (2014). Entrepreneurship, social welfare, and cultural values: Young peoples social attitudes in Finland. Advances in Business-Related Scientific Research Journal, 5(1), 13-24.

Rantanen, T., Pawlak, A., \& Toikko, T. (2015). The significance of social welfare attitudes in young people's intrepreneurial intentions. Entrepreneurial Business and Economic Review, 3(1), 43-60. https://doi.org/10.15678/EBER.2015.030104

Republic of South Africa. (1996). The Constitution of the Republic of South Africa, Act 108 of 1996. Retrieved from http://www.justice.gov.za/legislation/constitution/ SAConstitution-web-eng.pdf

Rueda, S., Moriano, J.A., \& Liñán, F. (2015). Validating a theory of planned behavior questionnaire to measure entrepreneurial intentions. Developing, Shaping and Growing Entrepreneurship, 68-78. https://doi.org/10.4337/9781784713584.00010
Shane, S., \& Venkataraman, S. (2000). The promise of entrepreneurship as a field of research. Academy of Management Review, 25(1), 217-226. https://doi. org/10.5465/amr.2000.2791611

Sinyolo, S., Mudhara, M., \& Wale, E. (2017). Assessing the impact of social grantdependency on participation of KwaZulu-Natal rural households in farming: Application of the generalised propensity score method. Journal of Agriculture and Rural Development in the Tropics and Subtropics (JARTS), 118(2), 233-244.

Small Enterprise Development Agency. (2016). The small, medium and micro enterprise sector of South Africa. Research Note 2016, No 1.

South African Social Security Agency (SASSA). (2017). You and your grants. Retrieved from http://www.sassa.gov.za/index.php/knowledge-centre/grant-booklets? start $=6$

Surender, R., Noble, M., Wright, G., \& Ntshongwana, P. (2010). Social assistance and dependency in South Africa: An analysis of attitudes to paid work and social grants. Journal of Social Policy, 39(2), 203-221.

The Citizen. (2017). Youth unemployment a ticking time bomb- SANCO. The Citizen. Retrieved from https://citizen.co.za/news/south-africa/1545055/youthunemployment-a-ticking-time-bomb-sanco/

Zeffane, R. (2013). Need for achievement, personality and entrepreneurial potential: A study of young adults in the United Arab Emirates. Journal of Enterprising Culture, 21(01), 75-105. https://doi.org/10.1142/S0218495813 500040

Zondo, M. (2017). Why social grants are a dead end for the youth. Retrieved from https://www.news24.com/Columnists/GuestColumn/why-social-grants-are-adead-end-for-the-youth-20170619 